\title{
К этимологии двух русских слов (бабочка и белобрысый)
}

\author{
Ю. В. XРАMOB \\ Flat 4, 38 Oak Grove, Cricklewood, London NW2 3LP, England \\ E-mail: hramov@tvnet.lv
}

(Received: 15 September 2015; accepted: 5 November 2015)

\begin{abstract}
This paper analyzes the Russian lexeme бабочка, offering to interpret it as an onomatopoeic word, connected by means of reduplication to the dialectal бякать 'to beat, to hit'. The paper also discusses the word белобрыссый 'tow-haired', which is problematic from the point of view of etymology. Developing V. Orel's hypothesis, the author offers to interpret this word as 'covered with white; sprinkled with white', connected to the interjection брысcь 'shoo' and to the verb бросать 'to throw'. The paper pays particular attention to the semantic and derivational aspects of the etymology of the word.
\end{abstract}

Keywords: Russian, East Slavic, etymology, onomatopoeic word, reduplication

1. Традиционно русск. бабочка связывается с баба, бабка и, по А. А. Потебне, трактуется как душа бабки, предка женского пола в связи с языческим представлением о том, что душа умершего продолжает жить в виде данного или других насекомых (см., например, с.-х. диал. babaciẽnka 'божья коровка') (ПотеБня 1883: 78, ФАСМЕР 1: 100, VÁŽNÝ 1955: 86-87, ${ }^{1}$ ЭССЯ 1: 106-107, 108-109, 115-116); см. также новейшие этимологические словари русского языка (ШАпошников 1: 40, Аникин 2: 25-26, OREL 1: 68). ${ }^{2}$ П. Я. Черных предлагал другое объяснение данного слова: от -бавить, диал. бава 'забава', 'игрушки', бавушка (ЧЕРных 1: 62-63).

Вполне возможная и оправданная мотивация, определяемая традиционной точкой зрения, на фоне индоевропейских и неиндоевропейских языковых фактов все-таки выглядит вторичной. Предположение о позднем сближении рассматриваемого слова со звукокомплексом *baba соотносится именно со славянским материалом, а другие языки, как правило, демонстрируют асимметрию между наименованиями бабочки (божьей коровки, стрекозы, пчелы и др.) и бабки: см., в частности, словарную статью «grandmother» в словаре К. Д. Бака (Buck 1949: 109-110) и нижеприведенную цитату из В. И. Шерцля.

Ценные примеры по нашей теме обнаруживаем в одной из работ Шерцля : «Для бабочки казалось бы весьма трудным придумать какое-нибудь

\footnotetext{
${ }^{1}$ Семантически иначе, чем А. А. Потебня: в основе названия бабочки лежит эвфемистическое название колдуньи $b a b a, b a b k a$.

${ }^{2}$ Подробнее о соответствии понятий душа и бабочка см. IMMISCH 1915.

${ }^{3}$ Автор уже неоднократно подчеркивал значение работ В. И. Шерцля для исторической семасиологии и лексикологии (см. ХРАМОВ 2006, ХРАМОВ 2008).
} 
ономатопоэтическое название, а тем не менее именно это насекомое в языках всех частей света изображается обилием слов звукоподражательных, рисующих, по-видимому, быстрое взмахивание и хлопанье его крыльев при его порхающем полете. При этом весьма замечательно, что многие названия бабочки в разнороднейших и совершенно отличных друг от друга языках обнаруживают удивительное сходство между собою. Достаточно указать на следующие слова, означающие бабочку: латинск. papilio, негритск. papals, грузинск. pepeli, мексиканск. papalotl, вакхийск. pilpilak, курмск. pilpiluk, удск. phephalak, тхушск. peplao, чиняньск. peperu, перуанск. piljpinta, новозеландск. pepepe, абхазск. pharphalik, Ундага (Афр.) pepêli, Пика (Афp.) pilpilo, pilphilo, Чарава (Афр.) pilipîli, мафурск. арор, тагитск. рере, самоанск. реререареа, баскск. pimpirina, Moce (Афр.) pilimpíko; ср. также зулусск. рарата (порхать о бабочке). К другим же выразительным звуковым группам, изображающим бабочку, принадлежат: индуст. titrî, titlî, арабск. farfûr, манджурск. tonton, баскск. čičitola, Сандех: fuffuruffú (в центр. Афр.), новоголл. walbulbul, ашантийск. afafanto, franfranta, мандингск. firifiri, чильск. патре-патре, анамск. kon-bim-bim, волофск. läpäläpä, гирканск. tcitcimkala, зырянск. bobuv, тагальск. paroparo, ботокудск. kiaku-kekk-kekk, бамбарск. fereferej и др. К латинск. papilio $^{4}$ примыкают: франц. papillon, итал. parpaglione, farfalla (шведск. farfall), ломбардск. parpaja, прованс. parpalhó, гасконск. parpailloun, англосак. fiffalde, баварск. feifalter, резьянск. pripilica, булг. peperuga, preperuga и др.» (ШЕРцЛЬ 1889: 174-175). ${ }^{5}$

В цитате из Шерцля обратим внимание на повторяющиеся в обозначении бабочки звуки $p, f, b$, которые в фонетическом плане согласуются с русским наименованием насекомого. Здесь уместно вспомнить об отражающем изобразительную способность определенных звукотипов термине идеофон, о необходимости введения которого в этимологическую лексикографию писал В. И. Абаев (см. АБАЕв 1986: 16-20). В этом смысле названия бабочки в самых разных языках мира не что иное, как определенный звукотип, или идеофон. Нельзя не упомянуть и работу В. Ёля, объяснявшего латинск. $p a-$ pilio и др. на основе общего для многих языков творческого принципа «элементарного звукоподражания», в данном случае «звуковой образности» или экспрессивности, отражающей зрительное впечатление от полета бабочки (OEHL 1922: 75-115). Любопытно, что, рассматривая слвц. babička 'пестрая дневная бабочка' в духе незвукоподражательной концепции, не до конца ясное славянское * motylb (об этом слове со списком литературы см., например, OREL 2: 296) В. Важный интерпретирует как экспрессивное образование на «трехтиповой» Звуковой основе $m+t+l$ (VÁžNÝ 1955: 30-35).

\footnotetext{
${ }^{4}$ У Ю. Покорного латинск. papilio и родственные формы восходят к и.-е. корню *pel'летать, порхать, дрожать, плавать и др.' (РОKORNY 1959: 798, 801).

${ }^{5}$ См. также лексический материал пособия по современной индоевропеистике: «For the 'butterfly' we have *pelpel- with related forms in Latin pāpiliō and Germanic (e.g. Old English fifalde) that have been clearly altered» (MALLORY-ADAMS 2007: 150).
} 
Возможно, русск. бабочка (правда, через ступень редупликации, что не исключено при звукоподражании, см. русск. глагол, колокол или примеры Шерцля) связано с такими диалектными формами, как бякаться 'падать', бякать 'ударять, бить; ронять, бросать что-л. со стуком, грохотом', бяк 'междометие, обозначающее падение или удар по кому-л. или чему-л.' (СРНГ 3: 358-359), 6 по-видимому, в конечном счете родственными с междометием баu! и аналогичными звукоподражаниями в других славянских языках; хотя, например, А. Аникин разделяет междометия бац! и бяк! (Аникин 5: 300-301).

2. До сих пор не получило удовлетворительного обоснования этимология русск. белобрысый, укр. білобрисий, блр. белабрысы. Пользуется популярностью гипотеза о связи белобрысый с бры- 'бровь' (ЭСБМ 1: 343, ЕСУМ 1: 196), см. также слова М. Фасмера о том, что это соотношение «несомненно» [zweifellos] (VASMER 1: 72). Но уже А. Вайян сомневался в правдоподобности этой версии (VAILlANT 1958: 273). Правда, альтернативное мнение Вайяна о якобы существовавших вариантах *rysŭ 'рыжий, пятнистый' (см. русск. pblcb) и *belorysyj 'белобровый человек, напоминающий рысь с белой шерстью’ (см. нем. Silberluchs) (VAILLANT 1958: 273) также нуждается в дальнейших доказательствах. В своей последней работе В. Орел высказал предположение о связи -брысый с бросать (OREL 1: 93), что, на наш взгляд, является вполне приемлемым решением, но требует дополнительной аргументации.

В современном русском языке по значению белобрысый - не только о светлых бровях, но и о светлых волосах и ресницах. Стоит также обратить внимание на стилистическую маркированность данной лексемы: «в просторечии» (см., например, ССРЛЯ 1: 374). У Даля присутствует помета «шуточное» (ДАль 1: 383) [сказывается простонародная реакция на альбинизм?].

Belobrovyj - общеславянское слово, по-видимому, возникшее в праславянский период (ЭССЯ 2: 69). Исходя из этого, не совсем ясно, почему, если следовать наиболее распространенной и практически общепризнанной гипотезе, именно в восточнославянской форме сохранена древняя *bry-. Белобрысый не отражается в памятниках русского, украинского и белорусского языков до XVIII века (ср. СРЯ XI-XVII вв., Тимченко, СУМ XVI-XVII ст., ГСБМ, СРЯ XVIII в. 1: 194). Все-таки это слово новое, а *-брысылй, кажется, связано с брысы! Среди попыток этимологизации брысы находим понимание данного слова как отглагольного образования, связанного с бры-снуть и т. п. (ЭСРЯ 2: 205, Аникин 4: 305). ${ }^{7}$ Однако В. Орел не разделял этой точки зрения (OREL 1: 138).

Интересно и то, что брысьь фиксируется только с XVI века (RIDLEY 1996: 74) и вполне могло быть соотнесено с *-брысый, ${ }^{8}$ хотя данное соотношение

${ }^{6}$ Сема 'издавать, производить звук, шум’ тут явно присутствует.

${ }^{7}$ Сюда же бры-кать, бры-згать, бро-сать (в современном значении с XVI в. - RIDLEY 1996: 74), npbl-скать, npы-щз и, возможно, другие слова, близкие в семантическом плане (см. СРНГ 3, СРНГ 33).

${ }^{8}$ См. прозвище белокурого человека Белобрыська (СРНГ 2: 216). 
могло быть и опосредовано вышеуказанными глагольными формами. В любом случае в истории русского языка наблюдалось взаимодействие брысь и *-брыссылй.

Также любопытно, что прилагательные с корнем -бров- встречаются чаще, чем с -бры-: см., например, тонкобровылй, светлобровый, темнобровый, рыжсебровый, густобровый и т. П., в названиях птиц - желтобровка, краснобровый тетерев (ССРЛЯ 3: 496, ССРЛЯ 12: 1617, ССРЛЯ 13: 337, ССРЛЯ 15: 247, 618; Даль 1: 1360, ДАль 2: 482). Чаще говорят чернобровый, не чернобрысый. У Даля есть чернобрысый в значении 'темно-русый' (ДАль 4: 1318), есть и седобрысый (СРНГ 37: 117), т. е. употребление слов с -брысый в большей степени ограничено как территориально, так и стилистически.

Всегда ли белобрысый было стилистически (особенно в плане оценочности, окраски) маркированным? Например, у А. С. Пушкина, как нам кажется, оно участвует в переосмыслении книжно-поэтического сравнения реки с «северной девой» (автор сравнения - Н. И. Гнедич) и является вполне нейтральным, сближенным с народно-разговорной сферой русского языка: «Один из наших поэтов, - отвечал ему другой, - сравнивал ее [Неву] с русской белобрысой красавицей» (ССРЛЯ 1: 374, Пушкин 5: 651, ГнЕдич 1956: 199).

Если брать во внимание не стилистику, а семантику, то зачем нужны слова с -брыл-? Для обозначения общего, без деталей портрета? Так сказать, «обрызганный белизной», т. е. первоначально белобрысый и белобровый соотносились как общее и частное: человек мог быть белобрысым, но необязательно белобровым. К тому же, абсолютная синонимия - явление редкое, да и то спровоцированное заимствованиями, поэтому видеть бры- 'бровь' в форме белобрысый при наличии белобровый было бы странным.

Нашим рассуждениям не противоречат данные белорусского и украинского языков. Из довольно-таки редких фиксаций анализируемого слова (его нет, например, в СУМ) в белорусских и украинских словарях выделяются две: блр. белабрысы 'блондин' (КАсьпяРОВІч 1927: 37) и укр. білобрисий 'белокурый’ (БІЛЕцьКИй-НосЕНко 1966: 55). Обратим внимание, что в этих примерах речь идет о волосах, а не о бровях. Также интересно, что в другом месте словаря Белецкого-Носенко подчеркивается оценочность в слове: білобриса 'беломордая, белокурая' (БІлЕцький-Носенко 1966: 62), здесь же указывается слово бриса 'морда', которое, правда, авторами ЕСУМ рассматривается как несуществующее: «існування слова *бриса 'пика' нічим не підтверджується» (ЕСУМ 1: 196).

В словообразовательном аспекте см. следующую параллель: бел-о-бры$c$-ылй = русск. диал. белокрысый ‘белокурый’ (СРНГ 2: 221) из бел-о-кры-с-ый 'покрытый белым' (от крыть). Любопытно, что более древние, праславянские образования от крыть (см. кры-ша, ЭССЯ 13: 70-71 или SP 1: 77) в современном языке представлены с другим суффиксом. Образование *белокрыmылй 'белокурый’ (см. модель беловышитый, СРНГ 2: 217) в языке не встречается, как кажется, по причине тесной связи белобрысый и белокрысый. В таком смысле суффикс -c- становится менее гипотетическим в сравнении 
с предположением о родстве белобрысый с *бры- (здесь нужно принимать воздействие по аналогии со словами белорусый или беловолосый, но даже в этом случае -c- является не суффиксом, а частью корня). Альтернативно предполагается, что белокрысый является результатом контаминации белобрысый и белокурый (Аникин 3: 77). Все-таки логичнее с точки зрения языковой системы рассматривать все три образования как отглагольные: см. -брысый от брызгать, бросать; -крысый от крыть; -курый от курить ; ${ }^{9}$ хотя для последнего слова есть и другая версия (см. Аникин 3: 77). По структуре здесь можно видеть менее продуктивную словообразовательную модель, хотя в старорусский и более поздний периоды в именной системе русского языка отмечается функционирование суффикса -ca (точнее -c-): ср. такие слова, как плакса, кукса и т. п. (подробнее см. KIPARSKY 1975: 253, 294). В тот же период встречаются и прилагательные с соответствующим суффиксом: например, в XVI в. плак-с-ивый (СРЯ XI-XVII вв. 15: 71).

\section{Литература}

АБАЕВ 1986 = АБАЕВ В. И. Как можно улучшить этимологические словари. В кн.: Этимология 1984. Москва, 1986. 7-27.

Аникин $=$ Аникин А. Е. Русский этимологический словарь. Т. 1-. Москва, 2007-.

БілЕЦьКИй-НОСЕНКО 1966 = БІлЕЦьКИй-НОСЕНКО П. П. СЛОвник украӥнської мови. Київ, 1966.

ГнЕдич 1956 = ГнЕдич Н. И. Стихотворения. Ленинград, 1956.

ГСБМ = Гістарычны слоўнік беларускай мовы. Вып. 1-. Мінск, 1982-.

Даль = Даль В. И. Толковый словарь живого великорусского языка. Т. 1-4. СанктПетербург-Москва, 1903-1909.

ЕСУМ = Етимологічний словник української мови. Т. 1-. Київ, 1982-.

КАСЬПЯРОВІч 1927 = КАСЬПЯРОВІч М. І. Віџебскі краёвы слоўнік. Віцебск, 1927. [Репринт: Менск, 2011.]

ПОтЕБня 1883 = ПотЕБня А. А. К истории звуков русского языка. Ч. 4. Варшава, 1883. Пушкин $=$ Пушкин А. С. Собрание сочинений в 10 томах. Москва, 1959-1962.

СлРЯ XI-XVII вв. = Словарь русского языка XI-XVII вв. Вып. 1-. Москва, 1975-

СРНГ = Словарь русских народных говоров. Вып. 1-. Ленинград, 1965-.

СРЯ XVIII в. = Словарь русского языка ХVIII века. Вып. 1-. Ленинград, 1984-.

ССРЛЯ = Словарь современного русского литературного языка. Т. 1-17. МоскваЛенинград, 1950-1965.

СУМ = Словник української мови. Т. 1-11. Київ, 1970-1980.

СУМ XVI-XVII ст. = Словник української мови XVI-першої половини XVII ст. Вип. 2.

Львів, 1994.

ТимченКО = Тимченко Е. Историчний словник украӥнського язика. Т. 1. Харків-Київ, 1930.

ФАСМЕР = ФАСмЕР Макс: Этимологический словарь русского языка.. . 1-4. Москва, 1986-1987.

\footnotetext{
9 Эта словообразовательная возможность подкрепляется и такими примерами, как беломойка 'чистоплотная женщина' (СРНГ 2: 222).
} 
ХРАмОВ 2006 = ХРАмов Ю. О семасиологических исследованиях В. И. Шерцля (18431906). К 100-летию со дня смерти ученого. Slavia 75 (2006): 401-406.

Храмов 2008 = ХРАмОв Ю. О забытых работах В. И. Шерцля. Acta Linguistica 2008/2: $73-78$.

ЧЕРнЫХ = ЧЕРнЫХ П. Я. Историко-этимологический словарь современного русского языка. Т. 1-2. Москва, 1999.

ШАПОШНИКОВ = ШАПОШНикОВ А. К. (сост.) Этимологический словарь современного русского языка. Т. 1-2. Москва, 2010.

ШЕРцЛЬ 1889 = ШЕРцЛЬ В. И. Основные элементы языка и начала его развития. Воронеж, 1889.

ЭСБМ = Этыммалагічны слоўнік беларускай мовы. Т. 1-. Мінск, 1978-.

ЭСРЯ = Этимологический словарь русского языка. Вып. 1-. Москва, 1963-.

ЭССЯ = Этимологический словарь славянских языков. Вып. 1-. Москва, 1974 .

Buck $1949=$ Buck C. D. A Dictionary of Selected Synonyms in the Principal Indo-European Languages. A Contribution to the History of Ideas. Chicago, 1949.

IMMISCH 1915 = IMMISCH O. Sprachliches zum Seelenschmetterling. Glotta. Zeitschrift für griechische und lateinische Sprache 6 (1915): 193-206.

KIPARSKY 1975 = KIPARSKY V. Russische historische Grammatik. Bd. 3. Entwicklung des Wortschatzes. Heidelberg, 1975.

Mallory-Adams $2007=$ Mallory J. P., AdAms D. Q. The Oxford Introduction to ProtoIndo-European and the Proto-Indo-European World. Oxford, 2007.

OEHL 1922 = OEHL W. Elementare Wortschöpfung: papilio - fifaltra - farfalla. In: Biblioteca dell' «Archivum Romanicum». Serie 2. Vol. 3. Genève, 1922. 75-115.

Orel $=$ Orel V. Russian Etymological Dictionary. Vol. 1-4. Calgary, 2011.

POKORNY 1959 = POKORNY J. Indogermanisches etymologisches Wörterbuch. Bern-München, 1959.

RIDLEY 1996 = A dictionarie of the vulgar russe tongue. Attributed to Mark Ridley. Edited from the late-sixteenth-century manuscripts and with an introduction by Gerald Stone. Köln, 1996.

$\mathrm{SP}=$ Słownik prasłowiański. T. 1-. Wrocław, 1974-.

VAILlant 1958 = VAiLlant A. Grammaire comparée des langues slaves. T. 2. Première partie. Lyon-Paris, 1958.

VASMER = VASMER M. Russisches Etymologisches Wörterbuch. Bd. 1. Heidelberg, 1953.

VÁŽNÝ 1955 = VÁŽNÝ V. Ojménech motýlů v slovenských nářečich. Studie sémasiologická se zřetelem jazykově zemépisným. Bratislava, 1955. 